\title{
Migracions i microestats
}

\author{
Jordi Domingo i Coll \\ Universitat de Lleida. Departament de Geografia i Sociologia \\ Plaça de Víctor Siurana, 1. 25003 Lleida (Spain) \\ jdomingo@geosoc.udl.es
}

\section{Resum}

Els països més petits d'Europa han transformat les seves bases econòmiques emparats en les possibilitats que els oferia el seu fet diferencial. La consecució d'una economia bàsicament terciària s'ha acompanyat d'un canvi en les funcions territorials i, especialment, d'un augment important de la població, de manera que han passat de ser societats emissores a ser societats receptores pel que fa als moviments migratoris. La composició de la població segons el seu origen mostra que aquestes societats tenen uns percentatges d'immigrants superiors al $60 \%$ en dos dels casos, i molt superior al $10 \%$ en la resta. Avui, els microestats europeus són l'expressió moderna de la ciutat estat d'altres èpoques, però, a més, s'han convertit en veritables societats multiculturals a les portes del segle XXI.

Paraules clau: microestats, Europa, migració, frontera, transformació econòmica, cultura, convivència multicultural.

\section{Abstract. Migrations and microstates}

The smallest European countries have transformed their economic bases from their specific situation. Their new economy based on service sector goes together with a change in territorial functions, and specialy, with an important increase in population. Referred to the migrations these societies have changed from emision ones to receivers. The population composition according to their origin shows and average above $60 \%$ of inmigrates, in two cases, and over $10 \%$ in the other cases. Today, the European microstates are the modern expression of the city-state characteristic of the past. But they have become truthful multicultural societies when starting the XXI century.

Key words: miscrostates, Europe, migration, boundary, frontier, economic change, culture, multicultural coexistence.

\section{Sumari}

1. Presentació 4. A mode de conclusió

2. Els microestats Bibliografia

3. La transformación de les bases

econòmiques 


\section{Presentació}

El fenomen migratori apareix relacionat, generalment, amb la idea de conflicte. L'essència del conflicte varia segons les condicions socials, econòmiques, culturals i polítiques de cada comunitat afectada. També varia segons les característiques de les comunitats receptores i de les comunitats emissores. Cal fer esment que el conflicte no és necessàriament negatiu, sinó que enfronta dues situacions o més i que aquesta trobada d'interessos també pot fer avançar una societat.

En les pàgines que segueixen s'analitzarà el fenomen de la migració i les causes que l'han motivada, en relació amb unes comunitats que, al llarg de la seva història, l'han experimentada en les dues vessants d'emissors i de receptors. Es tracta de quatre dels microestats europeus: Andorra, Liechtenstein, Mònaco i San Marino. No obstant la limitació del marc geogràfic en aquests quatre casos, també es farà referència a unes altres comunitats microestatals que poden aportar exemples sobre el tema.

La tria d'aquests quatre microestats obeeix al fet que presenten diferències en el moment en què es produeix el fenomen migratori i la seva intensitat. Al mateix temps, aquests quatre microestats presenten tipus diferents de conflicte atesa la presència d'immigrants i per les causes que han generat la seva arribada. En aquest sentit, els microestats es presenten com un espai semblant a un laboratori social on les causes que provoquen canvis es poden detectar, potser, més facilment, però al mateix temps presenten un grau d'interrelació difícil d'analitzar, ja que el nombre de nivells i determinacions externes que hi incideixen són més grans ${ }^{1}$.

Lanàlisi que segueix és fruit d'un procés d'investigació que va iniciar-se a meitat de la dècada dels vuitanta i que s'ha continuat fins a l'actualitat. El procés que s'ha seguit, a grans trets, es pot resumir en una primera fase de documentació i anàlisi de dades, un treball de camp in situ en cadascun d'aquests microestats, i una reflexió posterior de contrast amb l'afegit de noves dades que complementaven les fases anteriors. És per aquesta raó que moltes de les afirmacions que es trobaran a les pàgines que segueixen són fruit de l'observació i de les entrevistes realitzades en cada microestat que complementen les dades obtingudes a través d'altres estudis i obres consultades. Per realitzar aquesta anàlisi se situen, primerament, els microestats i algunes de les seves característiques més rellevants. Posteriorment s'analitzen les causes i els efectes de les migracions que els han afectat per acabar plantejant una idea de futur de les situacions creades en el procés.

1. Milton Santos (1986) analitza qüestions referides al mètode de treball i presenta la idea d'una relació inversament proporcional entre l'espai que es vol estudiar i els nivells d'influència externa, així com d'incidència dels propis fenòmens interns. La relació inversament proporcional, però, cal entendre-la després del resultat de la valoració qualitativa dels elements que té l'espai que es vol estudiar. 


\section{Els microestats}

Malgrat que no hi ha una única definició de microestat, el terme evoca una realitat estatal molt petita ${ }^{2}$. Les dues bases principals per a la seva definició han estat el territori, generalment des de la geografia ${ }^{3}$, i la població, des de la sociologia, la politicologia, l'economia i la mateixa geografia. Mentre que el criteri territorial no es pot acceptar per si sol a causa de la distribució variable que poden presentar els objectes geogràfics, i especialment la població, el criteri exclusivament demogràfic es fa difícil d'acceptar a causa de la seva variabilitat. La comparació entre societats que puguin ser mereixedores d'aquest adjectiu ho posa en evidència.

La combinació dels dos criteris, el territorial i el demogràfic, pot ajudar a trobar un punt d'equilibri als casos en els quals es pot aplicar l'adjectiu. Mallart (1988 i 1993) defineix els microestats com aquelles realitats estatals que tenen un territori inferior als $5.000 \mathrm{~km}^{2}$ i una població inferior al milió d'habitants, encara que es poden admetre excepcions en el límit demogràfic ${ }^{4}$. Mallart, a més, fa una distinció de base territorial entre els que resulten ser microestats grans i els que es poden considerar petits, aquests són els que no arriben a una superfície de $1.000 \mathrm{~km}^{2}$. De fet, els microestats petits són els més nombrosos, ja que suposen vint-i-cinc casos d'un total de vint-i-vuit.

El continent europeu té set microestats i només un, Luxemburg, es pot considerar "gran" segons el criteri anterior, que és el que s'aplica en l'anàlisi. Els microestats europeus tenen dues característiques específiques: són els únics que tenen una tradició política d'independència i són els únics continentals, amb l'excepció feta de la República de Malta, que és pluriinsular i va assolir la seva independència de la corona britànica l'any 1964.

Les comunitats microestatals europees s'han mantingut amb un o grau més o menys elevat d'independència al llarg dels darrers segles. Els seus veïns han canviat les fronteres pròpies, s'han format com a estats més grans i s'han expandit pel continent ${ }^{5}$. Els microestats, igual que altres estats europeus, tenen el

2. El terme microestat és relativament nou. La Societat de Nacions ja havia tractat el tema de l'adhesió dels estats lil.liputencs, i d'altres autors han utilitzat aquest adjectiu o el d'estats exigus (Stassinakis, 1995), o el d'estats minims (Pounds, 1985). Sembla que U-Thant, secretari general de l'ONU entre 1967 i 1971, va utilitzar públicament el terme microestat potser amb una connotació menys pejorativa que els altres. En l'actualitat el terme és d'ús corrent en els treballs científics.

3. Sobre les definicions que s'han ofert des de diverses àrees científiques es pot consultar, entre altres, Benedict (1967), Sanguin (1981), Dommen i Hein (1985).

4. Avui per avui, només dos dels microestats sobrepassen aquest límit d'un milió d'habitants. Es tracta de Singapur, amb més de tres milions d'habitants en un territori de $618 \mathrm{~km}^{2}$ i de Maurici, amb una població que recentment ha superat el milió de persones en un espai de $2.135 \mathrm{~km}^{2}$. La resta de microestats, segons la definició que se'n fa en aquestes pàgines, queda lluny, encara, de superar aquesta xifra.

5. Sovint s'ha exposat la idea d'una Europa vella, estable i, fins podria dir-se, cansada. Carreras (1993) i Calvez (1993), per contra, presenten el concepte d'una Europa dinàmica, en canvi constant $\mathrm{i}$ on les fronteres polítiques, un dels elements que poden aportar una idea més 
seu origen en l'Europa feudal i han arribat fins a l'actualitat elaborant unes estratègies, diferents en cada cas, que els han facilitat superar amb èxit els intents annexionistes dels estats veïns ${ }^{6}$. El procés històric que han viscut els ha permès crear, a més a més, una consciència de comunitat diferenciada amb els seus propis signes d'identitat ${ }^{7}$. Aquesta consciència és un element important $\mathrm{i}$ que cal tenir en compte, sobretot si es pensa que a principis del segle XX només un dels microestats estudiats superava clarament els 20.000 habitants.

Els microestats europeus no han estat, però, comunitats tancades a l'exterior. L'efecte que la frontera ha exercit en una comunitat que ha necessitat l'intercanvi econòmic, cultural i social amb els seus veïns, ha estat un altre dels elements que ha participat en la configuració de la seva identitat col-lectiva. La frontera és un element present en la vida del microestat, precisament a causa de la seva superfície. No hi ha cap part del territori microestatal que s'escapi a la influència directa del fet fronterer i de les dinàmiques que es poden crear ${ }^{8}$. $\mathrm{Cal}$ tenir present que es parla de comunitats que tenen en la seva superfície i població dues de les seves característiques principals. Mònaco no arriba a assolir els $2 \mathrm{~km}^{2}$, mentre que cap dels quatre microestats que centren l'anàlisi d'aquestes pàgines supera els 65.000 habitants. La frontera, encara que no s'utilitzi directament a nivell dels recursos econòmics de cada persona, sigui quina sigui la forma legal de la seva residència, és present en l'imaginari i en el simbolisme de qui habita en el microestat, en determina els límits legals de l'es-

gran d'estabilitat, s'han establert recentment i amb l'augment de socis de la UE han de variar encara més en els propers anys. Per altra part, una excel-lent anàlisi sobre Europa com a conjunt polític fragmentat i enfrontat es pot trobar a Foucher (1993).

6. Aquest fet ha donat lloc a diferents tipus de govern que avui poden resultar, si més no, rares perquè són poc habituals. El cas d'Andorra amb dos coprínceps, l'un el bisbe de la Seu d’Urgell i l'altre el president de la República francesa és únic. San Marino, per altra banda, manté una dualitat en la forma dels Capitani Regenti des del segle XII. Hi ha hagut autors que han posat en dubte la categoria d'estats per aquest tipus de raons en els casos d'Andorra i de Mònaco. Per altra banda, els intents annexionistes s'han superat amb èxit, el cas més emblemàtic és el de San Marino, que va superar el procés d'unificació italiana. Luxemburg, però, es va convertir en un microestat a partir de l'annexió d'algunes zones del seu territori per part de França i d'Alemanya.

7. Gotman (1952) assenyalava dues sèries de forces en la raó de ser d'un estat: la circulació i la iconografia. Mentre que la primera sèrie inclou tot tipus de moviment i representa un dinamisme, la segona designa el sistema de símbols en els quals creu un poble i tendeix a oferir una imatge d'estabilitat i de resistència al moviment. Sanguin (1975) defensa la idea que als microestats, al llarg de la seva història, la iconografia ha estat més forta que la circulació, fet que els ha permès formar-se com una entitat independent. No es pot oblidar, però, que el moviment també ha tingut els seus moments forts, justament quan aquests estats han transformat les seves bases econòmiques i socials. Un exemple de moviment es pot trobar quan el poble de Mònaco decideix unir-se a la jove república francesa sorgida de la revolució de 1789.

8. Sobre el tema de la frontera en relació amb els microestats es pot consultar Domingo (1997). Per altra banda, cal tenir present la definició de frontera que ofereix Foucher (1991), on explica que les fronteres són com «des structures spatiales élémentaires, de forme linéaire, à fonction de discontinuité géopolitique et de marquage, de repère, sur les trois registres du réel, du symbolique et de l'imaginaire» (p. 38). 
pai que ocupa i el diferencia del veí polític, amb qui en força ocasions es comparteixen trets culturals comuns. La frontera marca, també, el simbolisme i la legalitat de l'accés a la residència i de l'assoliment de la nacionalitat.

\section{La transformació de les bases econòmiques}

Els quatre microestats europeus que ocupen aquestes pàgines mostren una altra característica important. Han transformat, en el pas del darrer segle, les bases econòmiques que els eren tradicionals, passant de ser comunitats agrícoles $\mathrm{i}$ ramaderes a ser centres de negocis terciaris. Només Mònaco va iniciar aquesta transformació a mitjan segle XIX, amb la creació de la Societat dels Banys de Mar i del Cercle d'Estrangers que va impulsar l'obertura del casino de Montecarlo. En aquest procés cal esmentar el fet que la indústria ha estat la gran absent, i només en el cas de Liechtenstein ha tingut un pes important en la seva economia. L'aparició de l'activitat industrial ha estat complementària del procés de transformació que s'ha fonamentat en el sector terciari.

Aquesta transformació de les bases econòmiques ha seguit un camí diferent en cada microestat. No es pot establir una cronologia única que els assimili tots, però les bases de la transformació i els efectes han estat, pràcticament, els mateixos. De fet, el pas d'una economia tradicional a una altra de considerada, avui, més moderna no deixa de ser sinó una faceta del conflicte del qual es parlava en iniciar aquestes pàgines. Cada societat microestatal ha arribat a establir el procés del seu propi conflicte de transformació a partir dels elements interns i externs que actuen sobre la societat microestatal.

La transformació de les bases econòmiques es produeix en abandonar l'explotació dels recursos naturals tradicionals i iniciar un procés d'aprofitament de les rendes de situació a la periferia d'estats més grans i potents? . Aquest fet s'ha produït, en tots els casos, mercès a la influència d'elements aliens als propis microestats. Cal entendre que Andorra, situada entre França i Espanya, Liechtenstein, situada entre Suïssa i Àustria, i Mònaco, encerclada per França però amb Itàlia molt propera i a més amb litoral propi, han sabut jugar les seves possibilitats per aprofitar el factor diferencial. San Marino ha pogut aprofitar la renda de situació al costat de la costa de l'Adriàtic, propera a Rímini, un dels principals centres de turisme d'aquesta costa italiana. Tots han passat d'una economia de subsistència, que enviava part de la seva població a l'exterior en migracions generalment temporals, a una economia que ha generat unes rendes elevades i que ha necessitat de més mà d'obra de la que tenia per funcionar.

L'aprofitament d'aquestes rendes de situació apareixen, bàsicament, amb canvis que afecten l'augment de la mobilitat de les persones i dels béns de con-

9. Encara que es pugui parlar d'economies d'escala, el terme "potent» no vol comportar implicacions referides a la mida dels estats. En general, un estat gran té més possibilitats de diversificar la seva economia i aprofitar una varietat més gran de bases econòmiques. Sobre el tema es pot consultar un clàssic com Khalaf (1971). 
sum, amb l'augment de la capacitat de despesa de les classes treballadores i amb l'aparició d'un temps normatiu d'oci i lleure: les vacances. A més, també hi ha factors polítics que, d'una manera específica, afecten determinats microestats. És el cas de la Primera Guerra Mundial pel que fa a Liechtenstein, o la Guerra Civil espanyola i la Segona Guerra Mundial pel que fa a Andorra, per posar-ne dos exemples ${ }^{10}$.

El primer en experimentar aquest factor de transformació va ser Mònaco que, en perdre els municipis de Menton i Roquebrunne ${ }^{11} \mathrm{i}$ en firmar un tractat amb França, l'any 1860, va poder aprofitar l'impuls turístic que en aquells moments tenien Niça $\mathrm{i}$ altres ciutats properes de la costa francesa del Mediterrani ${ }^{12}$. La creació de la Societat dels Banys de Mar i del Cercle d'Estrangers, que va obtenir el monopoli del joc, va representar la base d'una transformació econòmica dedicada al terciari d'alta qualitat. La creació del casino de Montecarlo l'any 1866 va permetre abolir els impostos, l'any 1869, i atreure una part de l'alta burgesia europea i de la noblesa de l'època com a residents al petit principat dels Grimaldi ${ }^{13}$. Mònaco, que a mitjan segle XIX tenia al voltant dels cinc mil habitants, va arribar a multiplicar per sis aquesta xifra en els quaranta anys següents.

El cas d'Andorra va seguir passes molt diferents. Va ser l'aprofitament de l'energia elèctrica que es podia generar als seus rius la que va iniciar el procés de transformació d'una economia de muntanya. A partir de la creació de FHASA, amb capital exterior, els andorrans van tenir la possibilitat d'aprofitar la renda de situació entre França i Espanya, amb la millora d'infraestructures i d'una fiscalitat diferenciada. De tota manera, no va ser sinó després dels conflictes bèl-lics que van afectar Espanya, per un costat, i poc després França, per l'altre, que Andorra va poder treure un profit encara més gran d'una especialització comercial que suposava un trencament amb la base econòmica que havia tingut fins llavors. Andorra va passar de tenir prop de cinc mil habitants a principis de segle a tenir-ne al voltant de setanta mil als anys noranta ${ }^{14}$.

10. A més dels dos exemples exposats, es poden citar els casos de San Marino, amb la unificació italiana, i el de Mònaco, amb l'establiment de relacions amb França i les pretensions del Regne de Sardenya. A més d'aquests esdeveniments, es poden citar els d'inversions estrangeres, com en el cas d'Andorra i d'altres.

11. Aquests municipis havien decidit segregar-se de Mònaco per la quantia dels impostos que havien de pagar a la casa de Grimaldi. L'any 1848 es van declarar ciutats lliures sota el protectorat sard i van passar a formar part de França l'any 1861.

12. Les «rivieres» van ser els primers grans centres turístics d'acollida del Mediterrani. La Côte d'Azur és, a la vegada, la mes antiga i la més important «riviera» turística de la Mediterrània, amb un turisme d'alta qualitat desenvolupat des de mitjan segle XIX. Per més informació es pot consultar, entre altres, Lozato-Giotart (1991).

13. El turisme d'aquesta època era de luxe. Cal tenir present que l'explosió del fenomen turístic no arriba fins pràcticament cent anys després.

14. Sobre el tema d'Andorra es pot consultar Bricall (1975) i Lluelles (1991). El primer, en un estudi ja clàssic sobre el Principat, presenta una periodització de l'evolució dels factors econòmics d'Andorra, mentre que la segona realitza un estudi més profund i detallat sobre el procés de canvi de les bases econòmiques. Sobre la importància de l'emigració a Andorra, es pot consultar Tapinos (1987). 
Per la mateixa època però per causes ben diferents, en relació amb els efectes de la Primera Guerra Mundial, el principat de Liechtenstein va iniciar també un procés de transformació que l'havia de treure d'una situació pràcticament de ruïna. Liechtenstein tenia un tractat d'unió monetària amb Àustria. En acabar la Primera Guerra Mundial, amb la derrota dels austríacs, la moneda va perdre tot el seu valor, i Liechtenstein, que no havia participat en el conflicte, es va veure abocat a la misèria. Va ser llavors quan es va denunciar el tractat amb Austria i es va obrir a l'altre veí: Suïssa. A principis dels anys vint es va signar un acord d'unió postal, monetària i fronterera i Liechtenstein va poder aprofitar-se dels beneficis fiscals que havien fet de Suïssa un dels principals centres financers del món. Va acompanyar aquest fet de la implantació d'un conjunt d'indústries altament especialitzades i va abandonar la seva base econòmica tradicional. La població també va créixer, de menys de cinc mil habitants fins a vint-i-set mil a principis de la dècada dels noranta ${ }^{15}$.

Un altre cas diferent va ser el de San Marino. Aquesta república es va mantenir apartada del procés d'unificació italià, però va signar un conjunt d'acords amb el nou estat que l'encerclava absolutament. Com també va passar al país veí, els sanmarinesos van ser una comunitat amb fortes taxes d'emigrants, amb una base econòmica dedicada a l'agricultura i una petita indústria d'extracció. La seva transformació va ser provocada per l'impuls del turisme que va afectar la costa de l'Adriàtic i especialment la ciutat de Rímini. La transformació de la base econòmica tradicional per una altra de serveis dedicada al turisme i a un comerç que aprofitava la petita diferència fiscal amb Itàlia van empènyer el retorn dels emigrants ${ }^{16}$, fet pel qual San Marino té un percentatge de població estrangera menor que la resta de microestats europeus.

En els quatre casos el procés de transformació ha portat un conjunt de consequiències que han afectat no només la composició de la població, sinó també la seva economia i la seva estructura territorial interna.

La transformació econòmica en aquests quatre estats ha suposat, d'entrada, un augment de la població que ha superat l'estabilitat demogràfica a la quals estaven acostumats en unes economies de subsistència. Però no només s'ha produït aquest increment. El fet més important és que aquestes quatre comunitats eren emissores d'emigrants, si bé en molts casos només estacionals. Avui, aquestes comunitats són receptores de fluxos migratoris que si bé en un principi venien de comunitats veïnes, més endavant van començar a arribar d'altres indrets més allunyats.

L'increment de població es va produir acompanyant el desenvolupament d'una activitat terciària, però al mateix temps va anar desenvolupant una peti-

15. Liechtenstein vivia una situació de príncep absent. La derrota d’Àustria va portar la família Liechtenstein a residir al seu principat, cosa que no havien fet des de la seva adquisició. Sobre la història d'aquest principat alpí es pot consultar Seger (1984).

16. San Marino era una comunitat amb una taxa d'emigració important. Dos estudis sobre l'evolució de la població i el paper de l'emigració d'aquest microestat es poden consultar a Cavalleri (1985) i Guardigli (1985). 
ta indústria, moltes vegades relacionada amb la construcció. El microestat es va anar urbanitzant mentre es convertia en una moderna ciutat estat amb una economia que era necessàriament internacional, tant pel que fa als seus proveïdors com als seus clients. L'exemple més eloqüent és pot trobar a Mònaco, que aplega una de les densitats humanes més altes del món. Però també altres països, com Andorra o Liechtenstein i San Marino, presenten un entorn altament urbanitzat en el que es pot considerar una ciutat difusa que implica la totalitat del territori.

Aquest fet ha comportat uns canvis importants en el territori. Les funcions territorials que hi havia en temps d'una economia de base agrícola han deixat pas a un altre repartiment de funcions territorials adaptat a les necessitats de la nova economia. Si bé a tots els microestats es pot observar aquest canvi d'ús en les funcions territorials, el cas que pot servir més bé d'exemple és el de la localitat del Pas de la Casa a la parròquia d'Encamp d'Andorra. És una localitat que neix de les noves funcions terciàries d'Andorra, al costat de la frontera francoandorrana i que s'ha convertit en la localitat situada a més altitud de tot Europa $^{17}$.

Si s'exceptua el cas de Mònaco, on el territori presenta una diferenciació funcional per barris tot mantenint un continu urbà al llarg dels quasi $2 \mathrm{~km}^{2}$ de la seva superfície, en general s'ha reforçat la importància de la capital, mentre la resta del territori microestatal ha quedat com una part difusa integrada en les noves funcions urbanes. En alguns casos, a Liechtenstein i San Marino, principalment, hi ha hagut un increment d'altres localitats que han arribat a superar en nombre d'habitants i funcions econòmiques la pròpia capital. Així, la localitat de Schaan a Liechtenstein i la de Serravalle a San Marino s'han convertit en centres de l'activitat econòmica, amb la qual cosa s'ha trencat l'antiga estructura territorial. A Andorra, la segregació d'Escaldes, antiga localitat de la parròquia d'Andorra la Vella que forma un continu urbà amb la capital, és fruit del propi creixement que acompanya unes aspiracions que ja venien d'abans ${ }^{18}$.

En cada cas, els canvis territorials han modificat l'antiga estructura adaptantse a les exigències de les particularitats de les seves noves bases econòmiques. En general es pot dir que d'una repartició més o menys homogènia en el territori s'ha passat a una polarització que, des de la capital com a centre polític i en els casos citats anteriorment com a centres econòmics, es difumina pel territori fins a la seva frontera, on poden aparèixer petits focus d'activitat relacionada amb la proximitat de les duanes, quan aquestes existeixen.

17. La localitat del Pas de la Casa es troba situada a 2.075 m d'altitud i neix del resultat d'un fenomen transfronterer provocat per una situació comercial i turística. Sobre el tema, vegeu Lluelles (1995).

18. Les Escales-Engordany era una localitat adscrita a la parròquia d'Andorra la Vella, igual que la de Santa Coloma. L'any 1978 va aconseguir la seva segregació i es va configurar com a parròquia pròpia, sense que la frontera administrativa entre les dues parròquies hagi acabat de ser establerta. Avui, les Escaldes-Engordany és la segona parròquia més poblada del Principat, per darrere de la de la capital. 
L'increment de població ha estat un element important a l'hora de realitzar aquesta nova definició de les funcions territorials. Però convé analitzar un altre aspecte. La major part d'aquests increments s'han realitzat a partir de l'arribada d'immigrants, fins al punt que es pot parlar dels microestats europeus com dels estats que tenen un percentatge més baix de població autòctona en relació amb el conjunt total dels seus habitants. La immigració, a excepció de San Marino, on no arriba al 10\%, és majoritària a Andorra i Mònaco i arriba a superar el $40 \%$ a Liechtenstein. Unes proporcions similars a les d'aquests microestats es poden trobar a Luxemburg, amb més d'un $40 \%$ de la població d'origen estranger. El cas de Malta és més similar al de San Marino, amb unes taxes relativament baixes d'immigració.

Els efectes d'una composició tal de la població segons origen són evidents. Han convertit els microestats en societats multiculturals amb immigració de llarga durada en alguns casos i on la legislació interna ha hagut de regular un flux cada vegada més important de treballadors estrangers i posar unes bases per a la nacionalització que permetin reservar els caràcters locals. Cal tenir present que, malgrat que es parla d'un procés que s'ha produït al llarg de diverses dècades, aquest resultat és fruit d'unes circumstàncies socials, polítiques i econòmiques determinades que poden canviar, i que de fet ja ho han fet en els darrers anys. En aquest sentit, cal observar que les transformacions de les bases econòmiques dels microestats són produïdes com a efectes de canvis exteriors als mateixos interessats. Aquests canvis han generat processos d'adaptació interns que han afectat la legislació i la societat, a part de les funcions territorials a les quals s'ha fet menció més amunt. Com que la societat i l'economia són producte d'una evolució constant, cal entendre que els efectes sobre les condicions dels microestats evolucionen al mateix ritme, ja que, com s'ha apuntat anteriorment, l'economia d'aquests microestats és totalment internacionalitzada. Cada microestat ha evolucionat en aquest sentit. L'equip dirigit per Bricall (1975) ja reconeixia diverses etapes en l'evolució de l'economia andorrana basada en el tipus de resposta que oferien a la demanda exterior, i des de llavors encara ha tornat a canviar. Com a exemple basti exposar que el comerç d'Andorra ha evolucionat i que avui aquest comerç conviu amb una explotació turística que fa unes dècades era pràcticament impensable $^{19}$. En el cas de Mònaco, l'efecte del casino de Montecarlo ha deixat pas a una explotació diferent dels recursos del propi territori. Els congressos d'empreses, els negocis relacionats amb la seva fiscalitat $\mathrm{i}$ algunes petites indústries han donat lloc a una transformació del que havia estat un paradís del descans de grans fortunes europees i nord-americanes, per convertir el seu espai urbà en un espai de negocis que no té res a envejar al de qualsevol gran ciutat. Liechtenstein també ha

19. En aquest sentit hi ha hagut canvis importants en la relació amb Espanya i França pel que fa a l'horari d'obertura de les duanes amb el Principat d'Andorra. Si es parla amb residents andorrans d'una certa edat o amb catalans que anaven ocasionalment a Andorra, és facil comprovar la problemàtica existent fins als anys setanta pel que fa a la duana i a les comunicacions amb Espanya. El problema fronterer suposava, evidentment, un fre al desenvolupament del turisme. 
experimentat una transformació encara que en un sentit diferent. La industrialització que va generar la necessitat de molta mà d'obra estrangera ha deixat més protagonisme a un procés d'especialització terciària, menys necessitada de mà d'obra i per tant d'emigració, i en tot cas aquesta és selectiva i amb personal altament qualificat.

Si els factors del canvi en les economies microestatals van produir-se fora de les seves fronteres, cal veure que les societats veïnes també han canviat i que les diferències que podien existir entre els microestats i els seus veïns ja no suposen necessàriament un estímul per mantenir el mateix tipus de creixement. Aquest fet es deixa sentir, entre molts altres elements, en la composició de la població forana. Mentre que en un principi Andorra i Mònaco, i el mateix Liechtenstein, rebien immigrants de societats veïnes, l'origen dels immigrats ha canviat, ja que s'hi incorporen persones de societats més llunyanes. Aquest canvi ha comportat un augment de la diferència cultural dins de la societat microestatal que ha de realitzar un esforç més gran si vol mantenir els propis signes d'identitat col-lectiva, ja que l'imaginari comú que genera identitat queda diluït en una barreja important de cultures i d'interessos diferents ${ }^{20}$.

El cas d'Andorra és, potser, el més evident. En un principi la major part dels immigrants eren d'origen català, seguits per altres de la resta de l'Estat espanyol i pel col-lectiu francès. En els darrers anys els immigrants d'origen portuguès han superat en nombre els residents francesos, mentre que la proporció d'espanyols ha baixat, en part a causa de la nacionalització. Al mateix temps, s'hi han incorporat immigrants d'altres continents, especialment d'Âfrica, Amèrica i Àsia ${ }^{21}$. Com explica de manera encertada Lluelles (1993), a Andorra hi ha minories nacionals, algunes de les quals es troben afectades per un nivell d'ingressos baix. Els propis andorrans són una minoria nacional al seu territori a causa del gran volum d'immigrants que han rebut. De la mateixa manera, Liechtenstein i Mònaco han vist canviar l'origen d'una part dels seus immigrants, ja que si fins als anys setanta i vuitanta del segle XX arribaven des d'Europa, en l'actualitat arriben, també, d'altres continents. Cal, però, diferenciar els motius en cada un d'aquests estats. A Mònaco hi segueixen arribant residents de tot el món que trien aquest destí com a paradís fiscal i per les facilitats que ofereix per realitzar-hi negocis ${ }^{22}$. Al mateix temps, arriben a

20. Pot resultar interessant recordar el caràcter fronterer dels microestats. Sobre la problemàtica cultural en regions frontereres es pot consultar Goetschy i Sanguin (1995) i Sanguin (1993)

21. El canvi d'origen dels immigrants es pot relacionar amb els canvis que han afectat tant els països veïns d'aquests microestats, on en general ha augmentat el nivell de vida i les possibilitats de trobar-hi feina, al mateix temps que entren en els destins de les noves migracions econòmiques que afecten Europa en els darrers anys.

22. En aquest sentit, cal advertir que ha baixat el nombre de francesos residents a causa del conveni firmat amb aquesta república que en limita els efectes de paradís fiscal. A partir dels anys cinquanta dels segle XX, França fa pressió per evitar que les seves empreses tinguin tractament fiscal diferenciat al principat, segons els acords del 23 de desembre de 1951 (Freu et al. 1986). L'acord sotmet a la fiscalitat francesa els seus habitants residents a Mònaco durant els cinc primers anys. 
Mònaco, com a mà d'obra fronterera, immigrants dels que rep França. D’aquests es pot dir que no sempre es queden residint al principat mediterrani, $i$ això representa una discriminació econòmica a causa dels preus elevats que hi ha a Mònaco. Liechtenstein veu variar també l'origen dels seus immigrants. Mentre que en els anys cinquanta i seixanta havien anat a buscar mà d'obra a altres països europeus, com per exemple Espanya, per cobrir les necessitats de les seves indústries, en les darreres dècades arriben al principat alpí treballadors altament qualificats que treballen en procés de formació o adaptació a les empreses multinacionals del principat i que acostumen a residir-hi temporalment. També hi arriba mà d'obra menys qualificada que, a diferència de l'emigració de dècades anteriors, rarament resideix a Liechtenstein pels mateixos motius que es poden aplicar a Mònaco: els preus del sòl i del cost de la vida en general. Molts d'aquests treballadors resideixen a Àustria i Suïssa. L'ampliació dels orígens dels immigrants, quan aquests són treballadors poc qualificats, es pot relacionar amb una redistribució efectuada quan aquests arriben a països veïns dels microestats. La única excepció poden ser els treballadors portuguesos a Andorra, que sembla que hi arriben per xarxes de relació establertes des de l'origen.

La presència d'estrangers als microestats genera dues inquietuds. Per un costat hi ha el factor cultural, per l'altre, les possibilitats de mantenir el factor diferencial que ha permès als microestats consolidar la seva presència a través dels segles i avui gaudir d'una economia terciària internacionalitzada. Pel que fa al factor cultural, cal tenir en compte que una societat que ha anat construint els seus signes d'identitat al llarg de segles, i que li han permès mantenirse diferenciada dels seus veïns, amb qui hi ha hagut un contacte constant, pot veure's alterada per la presència d'una part numèricament molt important de persones que no comparteixen aquests signes culturals i que en la major part dels casos són immigrants que pensen en les possibilitats de retorn. Liechtenstein és potser el microestat que menys problemes presenta en aquest sentit, ja que els seus veïns comparteixen la mateixa llengua i l'immigrant moltes vegades ja no es queda a viure al mateix país. Els preus del sòl a Liechtenstein són molt elevats i a part dels immigrants de les primeres onades, la resta té una tendència a anar a viure a l'àrea austríaca propera a aquest principat dels Alps. En definitiva, no deixa de ser una estratègia que limita, juntament amb altres de caràcter molt local, la presència de persones estrangeres a la pròpia cultura.

Per altra banda, Mònaco ha vist com el seu dialecte local ha desaparegut del carrer en favor del francès. La internacionalització de la seva economia va portar al país a molts francesos ja en el segle XIX, mentre que al llarg del segle XX hi ha hagut un augment de residents d'altres països. En el cas de Mònaco cal destacar que els immigrants tenen una doble condició. Per un costat, hi ha els residents que es beneficien dels favors del paradís fiscal, mentre que, per l'altre, hi ha els immigrants que van a treballar a les indústries i els serveis del país. Mentre que els primers poden viure i pagar els preus del sòl d'aquest país, els segons resideixen habitualment a França i a Itàlia, i es desplacen diàriament al principat, en una migració pendular considerable. 
El cas d'Andorra presenta una altra vessant. Si bé és cert que hi ha una migració pendular diària des de la Seu d'Urgell, principalment, hi ha un important col-lectiu de residents estrangers. Treballadors i persones que regenten negocis, sobretot comerços i altres establiments de serveis, han provocat la necessitat d'un augment de l'espai construït als nuclis de població d'Andorra la Vella i les Escaldes-Engordany, principalment, però que influït per les dinàmiques urbanes modernes ha comportat un augment de residència en urbanitzacions situades fora dels nuclis urbans tradicionals. La cultura andorrana, molt relacionada històricament a la cultura catalana, ha viscut una pèrdua de terreny amb la presència de l'espanyol, del francès i del portuguès. Si bé el català segueix essent la llengua oficial d'Andorra, la presència quotidiana de les llengües majoritàries dels seus estats veïns és un fet incontestable.

San Marino no experimenta situacions similars. La transformació de la seva base econòmica ha permès el retorn dels emigrats, fet que ha suposat un increment de població notable amb un capital que s'ha invertit en el propi país. Les estretes relacions de San Marino amb la societat italiana ha fet que la llengua sigui la mateixa $i$, a part de signes locals d'identitat, no sembla que hi hagi diferència entre els dos costats d'una frontera que no té duana ${ }^{23}$.

Els processos de canvi i transformació cultural dels microestats seguiran produint-se de la mateixa manera, ja que no es pot concebre una cultura estàtica en el temps i l'espai. Les aportacions que des del fenomen migratori es poden produir poden accelerar el canvi en alguns aspectes i poden acabar ferint la base de l'imaginari col-lectiu que ha estat la base de la consolidació d'una societat diferenciada i amb un sentiment de pertinença altament desenvolupat pel mateix fet fronterer que els afecta. De tota manera, cal pensar que societats que han anat construint els eixos de la seva pròpia escala de valors nacionals poden adaptar les bases sobre les quals es mantenen per evolucionar en el futur. En aquest sentit, és el conflicte de què es parlava al principi d'aquest text el que permet evolucionar les bases microestatals, ajuntant-ho amb els canvis econòmics que els han acabat convertint en estats urbans o en l'expressió moderna de les ciutats estat de l'antiguitat.

\section{A mode de conclusió}

Si bé la immigració que han experimentat aquests quatre microestats ha estat fruit d'una transformació econòmica bastant accelerada, cal plantejar-se que les condicions que la van permetre han canviat. Avui Andorra, Mònaco i San Marino són estats perforadors de la Unió Europea, als quals cal sumar-hi

23. Ja s'ha fet menció abans sobre el paper de la frontera en els casos dels microestats. En l'exemple de San Marino s'hi pot afegir que aquesta frontera va ser amenaçada de tancament per part del govern italià quan el govern de la República sanmarinesa va decidir l'obertura d'un casino, que es van veure obligats a tancar per les pressions rebudes (Ballarino, 1990). Se'n poden trobar exemples semblants en altres ocasions, Andorra va tenir problemes similars en voler crear una emissora radiofonica que els francesos van rebutjar. 
Liechtenstein associat amb Suïssa. És aquest organisme internacional el que s'ha convertit en el seu interlocutor, i imposa unes condicions diferents de les que podien obtenir dels seus veïns directes. Ja abans d'aquest canvi, els microestats han anat adequant la seva realitat als canvis socials i econòmics que s'han anat produint.

Fins ara les transformacions han permès, en línies generals, adaptar les seves estructures per produir un creixement econòmic i de població més elevat. Però els criteris de la Unió Europea pot ocasionar canvis importants en el que s'havia convertit en la base d'unes economies terciàries. Andorra és, potser, qui ha notat més aquesta nova situació. El comerç, que havia estat la base del seu desenvolupament terciari, ha perdut presència en favor d'un increment del turisme estacional, que no necessita tanta mà d'obra resident. Per altra part, altres indrets dels Pirineus, ja sigui espanyol o francès, han incrementat l'oferta turística en el mateix sentit, i les noves formes de distribució s'han imposat creant una competència a l'economia andorrana. Cal tenir present que el turisme necessita unes infraestructures que ocupen territori i que, si l'increment de l'oferta turística es realitza sense una planificació, pot acabar per fer malbé el capital en forma de paisatge amb el qual es compta.

Per la seva banda, Mònaco ha anat canviant de centre de vacances de l'alta burgesia europea i nord-americana per passar a ser un centre de serveis d'alta qualitat que es complementa amb una petita indústria poc contaminant i que ocupa poc espai. Les necessitats de mà d'obra s'han estancat i en tot cas els treballadors ja no van a viure al propi principat, d'igual manera que passa a Liechtenstein. Els preus del sòl actuen en aquest sentit, de la mateixa manera que passa a Andorra, encara que a una escala menor.

Els microestats, doncs, representen unes realitats polítiques i econòmiques que han passat de ser focus emissors d'emigrants a ser-ne focus receptors. El canvi s'ha produït a partir d'una transformació de la seva base econòmica que ha comportat un augment accelerat de població, la major part de la qual és d'origen estranger. Aquesta situació obre dos interrogants de cara al futur: podran els microestats mantenir una economia que generi una tal necessitat de mà d'obra en un món cada vegada més gobalitzat?, i, la que pot ser més interessant, podran els microestats conviure amb generacions nombroses de fills d'immigrants que no necessiten integrar-se en els processos culturals que han permès mantenir els microestats com a entitats independents al llarg de segles? La resposta no es pot conèixer, ara per ara. Un element a favor dels microestats ha estat la tradicional capacitat per adaptar-se ràpidament als canvis que s'han produiit al seu entorn, però cal no oblidar que en aquells moments els microestats, malgrat que mantenien relacions amb les societats veïnes, eren societats marginals en el mapa polític europeu. Ara aquest mapa està canviant.

Per altra banda, els canvis econòmics i socials que es produeixen en els darrers decennis poden portar a una especificitat més gran del tipus de residents estrangers. Si en tots els microestats s'hi ha generat una doble tipologia d'immigrants, els uns que arriben com a mà d'obra i els altres que hi van a residir, encara que sigui de manera més o menys fictícia, per aprofitar els avan- 
tatges fiscals, la tendència actual és la de retallar l'arribada dels primers per afavorir els de la segona tipologia. Aquesta tendència torna a ser generada més a l'exterior de les fronteres microestatals que no pas al seu interior. Pel que fa a l'exterior, cal recordar que els microestats europeus són, avui per avui, estats encerclats per la Unió Europea, que té convenis sobre immigració exterior i que ha creat un espai social propi. També en la seva vessant exterior hi ha les línies que marca l'evolució de l'economia, que, entre altres direccions, apunten a una progressiva restricció dels paradisos fiscals, mentre que, pel que fa als motius que actuen des de l'interior, es mostra una progressiva especialització en l'ús de la mà d'obra d'acord amb un procés d'assentament dels canvis que s'han produït en els darrers decennis. L'evolució futura ho decidirà.

Els microestats, però, han aconseguit mantenir una independència política, adaptant-se de manera constant a les evolucions internes i externes. Avui són representants, sovint oblidats, de veritables societats multiculturals, i en aquest cas per motius molt diferents es poden incloure en l'afirmació el conjunt dels microestats del planeta. Els corrents migratoris que els han afectat, sobretot els que els han convertit en societats receptores, han estat una de les pedres angulars del seu desenvolupament econòmic, ja que han participat activament en la satisfacció d'unes necessitats que la transformació econòmica havia generat. La societat que en sorgeix és diferent de la que havia generat aquests canvis, segurament impensats en el seu moment, però és la representant d'una societat que ha mantingut els seus signes d'identitat al llarg dels segles i la que ha de decidir si els vol conservar a despit de totes les transformacions.

\section{Bibliografia}

Ballarino, T. (1990). L'evolució de la personalitat internacional de San Marino. Text policopiat.

BENEDICT, B. (ed.) (1967). Problems of smaller territories. Bristol: University of London \& Atholone Press.

BRICALL, J.M. et al. (1975). Estructura i perspectives de l'economia andorrana. Barcelona: Edicions 62.

CALVEZ, J.I. (1993). «Europe: la signification politique d'un grand project international». A MERLE, M. Les relations internationales à l'épreuve de la science politique. París: Economica.

CARRERAS, C. (1993): «O novo mapa da Europa». A SANTOS, M. et al. O novo mapa do mundo. Fim de século e globalizaçao. Sao Paulo: HUCITE-ANPUR, p. 129-138. CAVAlleri, G. (1985). «San Marino fouri San Marino». A AA.VV. Storia Illustrata della Repubblica di San Marino. San Marino: AIEP, vol. 2, p. 381-396.

Domingo, J. (1997). «Frontera i microestat». A Domingo, J.; Mallart, L. A l'entorn de la frontera. Vilassar de Mar: Oikos Tau.

Dommen, E.; HeIn, Ph. (1985). States, Microstates and Islands. Londres: Croom Helm. FOUCHER, M. (1991). Fronts et frontières. Un tour du monde géopolitique. París: Fayard. - (dir.) (1993). Fragments d'Europe. París: Fayard.

Freu, J. et al. (1986). Histoire de Monaco. Mònaco: Ministère d'État. 
GOETSCHY, H.; SANGUIN, A.-L. Langues régionales et relations transfrontalières en Europe. París: L'Harmattan.

Gotman, N. (1952). La politique des États et leur géographie. París: Gallimard.

GuARDigLI, P.P. (1985). «L'emmigrazione». A AA.VV. Storia Illustrata della Repubblica di San Marino. San Marino: AIEP, vol. 2, p. 365-380.

KHALAF, N.G. (1971). Economic implications of the size of nations. Leiden: E.J. Brill. LOZATO-GIOTART, J.P. (1991). Mediterráneo y turismo. Barcelona: Masson.

LLUELles, M.J. (1991). La transformació econòmica d'Andorra. Barcelona: L'Avenç.

- (1993). "L'économie de l'Andorre et la place des minorités ethniques». A SANGUin, A.-L. Les minorités ethniques en Europe. París: L'Harmattan, p. 279-284.

- (1995). "Le Pas de la Casa, paroxysme du phénomène transfrontalier andorran». A GOETSCHY, H.; SANGUIN, A.-L. Langues régionales et relations transfrontalières en Europe. París: L'Harmattan, p. 273-284.

Mallart, Ll. (1989). Microstats: un camí per al seu coneixement. Andorra la Vella: Andorra Govern, Conselleria d'Educació i Cultura.

- (1993). "Cultura territoriale, senzo di appartenza, microstati». A AA.VV. Alle origini dei territori locali. Università degli Studi della Repubblica di San Marino. San Marino, p. 71-80.

Pounds, N.J.G. (1985). Manual de Geografía Política. Milán: Franco Angeli.

SAnguin, A.-L. (1973). Les micro-états d'Europe (Andorre, Liechtyenstein, Monaco et Saint Marin). Géographie politique et économique. Université de Liege. Tesi doctoral. Text Policopiat.

- (1981). Geografía Politica. Vilassar de Mar: Oikos Tau.

- (1993). Les minorités ethniques en Europe. París: L'Harmattan.

Santos, M. (1986). "Espacio y método». Geocrítica. Revista de Geografía. Barcelona: Universitat de Barcelona.

STASsinAKIS, G. (1995). «Les états exigus et la Conference de la Paix de 1919». A GHEBALI, V.-Y.; KAPPELER, D. (coord.). Les multiples aspects des relations internationales. Brusseles: Bruylant. p. 69-80.

SEger, O. (1984). Abrégé de l'Histoire du Liechtenstein. Vaduz: O.P.I. Govern del Principat de Liechtenstein.

TAPINOS, G. (1987). Rapport sur l'immigration en Andorre. Diagnostic et perspectives. Text policopiat. 